Denne artikkelen finnes også i engelsk utga ve. Publiserings dat o: 14.05.2018

\title{
Operasjonssykepleiere mangler tid og kompetanse til å arbeide kunnskapsbasert
}

Operasjonsavdelinger og utdanningsinstitusjoner mangler en organisatorisk struktur og kultur som støtter opp om kunnskapsbasert praksis. Det kan påvirke pasientsikkerheten.

\section{Forfattere}

\section{Wenke Hjelen}

Universitetslektor

Institutt for sykepleie og helsefremmende arbeid, Fakultet for helsefag, Oslomet storbyuniversitetet

\section{Mette Sagbakken}

Førsteamanuensis

Institutt for sykepleie og helsefremmende arbeid, Fakultet for helsefag, OsloMet storbyuniversitetet

\section{Nøkkelord}

$\begin{array}{lllll}\text { operasjonssykepleie Fagutvikling kunnskapsbasert praksis Holdninger } & \text { Fokusgrupper }\end{array}$

Sykepleien Forskning 2018 13(69422)(e-69422)

DOI: https://doi.org/10.4220/Sykepleienf.2018.69422

\section{SAMMENDRAG}

Bakgrunn: Medisinskteknisk utstyr og medisinsk behandling er i stadig utvikling. Det medfører bedre og flere behandlingstilbud og behandlingsmetoder, som derved stiller særegne krav til faglig oppdatering og bevissthet for dem som jobber kunnskapsbasert. 
Hensikt: Hensikten med studien var å få innsikt i hvilken forståelse operasjonssykepleiere har av konseptet «kunnskapsbasert praksis» (KBP), samt hvilke erfaringer de har med å jobbe kunnskapsbasert. Ved å inkludere forskjellige sykehus ønsket vi å kartlegge ulike praksiser eller systembetingete forskjeller, som holdninger og tid avsatt til å arbeide kunnskapsbasert.

Metode: Vi gjennomførte fire fokusgrupper i tre ulike deler av landet. Fokusgruppeintervjuene ble foretatt i oktober til november 2012 og besto av fire til seks operasjonssykepleiere.

Resultat: Sykepleierne fremhevet at et stadig økende krav til produksjon og effektivitet var barrierer mot å jobbe kunnskapsbasert. De uttrykte at manglende kunnskaper kunne skape utrygghet i utøvelsen av arbeidet. Samtidig viser funnene at de ikke alltid benyttet mulighetene og tiden til å jobbe kunnskapsbasert slik det var tenkt. Tilgjengelige rom og pc-er i operasjonsavdelingene ble lite brukt til å søke, lese og vurdere fag- og forskningsartikler.

Konklusjon: Studien viser manglende kompetanse blant operasjonssykepleierne samt en manglende organisatorisk struktur og kultur som underbygger og støtter opp om KBP, både i operasjonsavdelingene og i utdanningsinstitusjonene. Funnene antyder at disse momentene kan ses i sammenheng med manglende tilrettelegging, men også manglende engasjement, både på et individuelt og organisatorisk plan.

En stadig utvikling av medisinskteknisk utstyr og medisinsk behandling medfører bedre og flere behandlingstilbud og behandlingsmetoder. Det stiller særegne krav til faglig oppdatering og bevissthet når det gjelder å jobbe kunnskapsbasert (1-3). I 2011 døde til sammen 14095 norske pasienter på sykehus, og en vesentlig andel av pasienter som dør på sykehus, knytter seg til pasientskade (4).

\section{2014 varslet spesialisthelsetjenesten om 414 uheldige} og/eller alvorlige hendelser til Statens helsetilsyn. Av disse var 38 klassifisert som hendelser knyttet til kirurgiske inngrep (1). Noen av hendelsene knyttes til kirurgiske komplikasjoner som oppsto under eller etter inngrepet. Noen komplikasjoner omhandlet imidlertid skade på grunn av leiringsfeil, hvordan pasienten blir lagt på operasjonsbordet under inngrepet.

Det var også hendelser med plutselig dødsfall på grunn av hjerteinfarkt, blodpropp eller vanskeligheter knyttet til utførelse av anestesi (1). Vi kan derfor fastslå at slike hendelser oppstår relativt ofte. Skader eller dødsfall knyttet til operasjoner brukes ofte som eksempler når man snakker generelt om uheldige hendelser i helsetjenesten $(1,5,6)$. 


\section{Kunnskapsbasert praksis}

Innenfor det som beskrives som «kunnskapsbasert praksis» (KBP), er det viktig å basere kliniske beslutninger på oppdatert og forskningsbasert kunnskap når den finnes. I tillegg inneholder konseptet KBP erfaringsbasert kunnskap, det vil si klinisk ekspertise og skjønn, refleksjon og taus kunnskap. Det å innhente kunnskap fra brukere av helsetjenestene er også en viktig dimensjon i KBP (7).

Det foreligger flere studier som har identifisert ulike barrierer mot å jobbe kunnskapsbasert (3, 7-10). Barrierene knyttes blant annet til uvitenhet om at sykepleieforskning finnes og kan benyttes til å endre praksis samt lite erfaring med å innhente relevant og oppdatert kunnskap via forskning. Det er også en barriere at forskning oppfattes som uklar og vanskelig å lese $(8,9,11,12)$.

Andre fremtredende funn er knapphet på tid i arbeidstiden, fag- og forskningslitteratur som ikke er samlet på ett sted, mangel på rom med tilgang til pc samt vansker med å implementere nye tiltak på grunn av motstand fra ledere og leger $(3,7-9,12)$. Nyere forskning viser en positiv holdning til KBP. Likevel er det utfordringer med tidsmangel og manglende støtte fra ledere i arbeidet med å vurdere og implementere nye tiltak $(10,13-15)$.

\section{Hensikt med studien}

Denne artikkelen beskriver resultatene fra en kvalitativ studie med fokusgruppeintervjuer av operasjonssykepleiere fra ulike deler av landet. Hensikten med studien var å få innsikt i hvilken forståelse operasjonssykepleiere har av konseptet KBP, og hvilke erfaringer de har med å jobbe kunnskapsbasert. På bakgrunn av denne hensikten utarbeidet vi to forskningsspørsmål:

- Hvordan forstår operasjonssykepleiere konseptet kunnskapsbasert praksis? 
- I hvilken grad og på hvilken måte arbeider operasjonssykepleiere kunnskapsbasert?

\section{Metode}

Studien har et kvalitativt design, og vi gjennomførte fire fokusgrupper. Vi valgte fokusgrupper fordi dynamikken som oppstår, gjør metoden velegnet til å belyse kunnskap om, erfaringer med og holdninger til utøvelse av KBP (16). Fokusgruppeintervjuene ble utført i oktober til november 2012 og besto av henholdsvis fire til seks operasjonssykepleiere.

Vi foretok et strategisk utvalg, der vi inkluderte tre sykehus fra ulike deler av landet. Ved å inkludere ulike sykehus kunne vi avdekke forskjellige praksiser basert på ulik utdanningsbakgrunn eller utdanningsinstitusjon, eller systembetingete forskjeller innad i sykehusene, som for eksempel tid avsatt til fagutvikling.

Vi kontaktet de administrative lederne ved de ulike operasjonsavdelingene på telefon. Lederne ble informert om studiens hensikt og metode, og de ble forespurt om å bistå med rekruttering. Vi rekrutterte deltakere med arbeidserfaring i operasjonsavdeling fra 2 til 40 år. De fleste jobbet i 100-prosentstilling, og ingen hadde lavere stillingsandel enn 70 prosent. Utvalget besto av kvinner fordi det ikke var noen mannlige operasjonssykepleiere ved de respektive avdelingene.

\section{Datainnsamling}

Operasjonsavdelingene stilte lokaler til disposisjon, og alle fokusgruppediskusjonene ble derfor foretatt i de respektive sykehusene. Vi utførte ett av fokusgruppeintervjuene i arbeidstiden og tre etter endt arbeidsdag. Fokusgruppediskusjonene varte fra 60 til 80 minutter. På bakgrunn av forskningsspørsmålene utarbeidet vi en intervjuguide. Hovedspørsmålene i intervjuguiden var som følger:

- Hva legger dere i begrepet kunnskapsbasert praksis? 
- Hvordan og hvor ofte innhenter dere ny kunnskap?

Intervjuene ble foretatt med førsteforfatter som moderator. I tillegg til brede, åpne spørsmål relatert til KBP og fagutvikling stilte vi spørsmål om rutiner og strukturer i avdelingen. Det kan være en fordel at moderatoren har adekvat bakgrunnskunnskap om temaet som blir diskutert. Dermed kan vedkommende ha ulike perspektiver på det som blir diskutert, samt følge opp viktige elementer innen temaet (16).

Vi erfarte at det var et godt utgangspunkt at moderator, hadde bakgrunn som operasjonssykepleier. Imidlertid kan moderatorens kunnskap om det tematiske feltet ha medført at det som blir ansett som allment kjent kunnskap blant operasjonssykepleiere, ikke ble integrert i diskusjonen.

\section{Etiske hensyn}

Det var ikke nødvendig å søke om tillatelse av Regionale komiteer for medisinsk og helsefaglig forskningsetikk (REK) for denne studien. Søknaden til Norsk samfunnsvitenskapelig datatjeneste, nå kalt Norsk senter for forskningsdata (NSD), ble godkjent før prosjektet startet. Lederne i de respektive avdelingene informerte alle deltakerne muntlig og skriftlig om studien.

I forkant av intervjuet gjentok moderatoren informasjonen om studien og deltakernes rett til å trekke seg. Etiske retningslinjer knyttet til konfidensialitet og avidentifisering av data er ivaretatt (17). Dataene ble kryptert og oppbevart på passordbeskyttet pc.

\section{Analyse}


Vi analyserte funnene ved å bruke Malteruds (18) modifiserte utgave av Giorgis fenomenologiske analyse. Målet med analysen var å bringe frem operasjonssykepleiernes egne opplevelser og erfaringer, og vi fokuserte både på gruppen og hver enkelt operasjonssykepleier. I analyseprosessen ønsket vi å identifisere hvordan operasjonssykepleierne forsto KBP, og i hvilken grad og på hvilken måte de arbeider kunnskapsbasert. Dermed måtte vi innhente informasjon om arbeid eller manglende arbeid med KBP i operasjonsavdelingene samt identifisere sammenhenger og motsigelser i det som ble formidlet.

I første del av analysearbeidet leste vi de transkriberte tekstene grundig gjentatte ganger. På denne måten fikk vi et helhetsinntrykk av hvilke meninger og mønstre som trådte frem. I neste trinn gjennomgikk vi intervjuene systematisk. Vi fokuserte på å identifisere meningsbærende beskrivelser av fenomener som fokusgruppene belyste, og som bidro til kunnskap om problemstillingen.

Intervjuguidens hovedpunkter ble benyttet for å lage koder, det vil si merkelapper som skulle samle tekstbiter som hadde noe felles. Slike tekstbiter ble systematisert og satt i følgende kolonner:

- Hvordan forstår operasjonssykepleiere konseptet kunnskapsbasert praksis?

- Hvordan og hvor ofte innhentes ny kunnskap?

Deretter sammenliknet vi og vurderte meningsbærende enheter fra samme kolonne fra hvert fokusgruppeintervju for å få en dypere forståelse av det som trådte frem av viktige mønstre og nyanser. Vi formulerte følgende kategorier:

- fagutvikling versus KBP

- fremmer fagutvikling

- hemmer fagutvikling

- avdelingskultur 
Konseptet KBP ble i denne delen av analysen satt opp mot begrepet «fagutvikling», da svært få sykepleiere brukte eller hadde en klar forståelse av KBP, noe som i seg selv representerte et funn. I trinn tre vurderte vi kodene som representerte grunnlaget for kategoriene, kritisk. Potensielle temaer ble utviklet, og sammenhenger mellom meningsbærende enheter, koder, kategorier og temaer ble synliggjort. I trinn fire vurderte vi meningssammenhenger i temaene kritisk opp mot datamaterialet i sin helhet. Vi identifiserte tre ulike hovedtemaer:

- strukturelle forhold

- holdninger og ansvar for eget fag

- kompetanse og kunnskap knyttet til kunnskapsbasert praksis

\section{Resultater}

Funnene viser til dels manglende kunnskaper om, forståelse av og bruk av konseptet eller begrepet KBP. Samtidig viser funnene at deltakerne allerede arbeider med deler av konseptet KBP. Erfaringskunnskap, som refleksjon og det å dele klinisk erfaring med hverandre, står frem som viktige strategier som benyttes for å heve kompetansen og øke pasientsikkerheten. En fokusgruppedeltaker sier det slik:

«Vi lærer av hverandres erfaringer. Vi kan ha forskjellige erfaringer med forskjellige ting, og hvis du er usikker på noe, så innhenter du den som var med på det sist. 'Hvordan gjorde du egentlig akkurat dette?'»

\section{三 «Mangel på tid fremstår som en av hovedbarrierene mot det å søke, lese og vurdere fag- og forskningsartikler.»}


De fleste deltakerne har derimot lite bevissthet rundt og erfaring med forskningskunnskap som en del av konseptet KBP, noe som utpekte seg som et hovedfunn i denne studien. Funnene viser også at mangel på tid fremstår som en av hovedbarrierene mot det å søke, lese og vurdere fag- og forskningsartikler.

Samtlige operasjonssykepleiere snakket om økende krav til produksjon og effektivitet. En travel arbeidssituasjon samt få ressurser på jobb ble fremhevet som viktige barrierer. Samtidig viser funnene at avsatt tid til å jobbe kunnskapsbasert ikke alltid blir benyttet som tiltenkt, og at fritiden anses som «hellig».

\section{Strukturelle forhold og ansvar for eget fag}

For at operasjonssykepleiere skal kunne øke pasientsikkerheten, må de planlegge og prioritere tid til å arbeide med faglig utvikling og oppdatering. Denne utfordringen vektla deltakerne i samtlige fokusgrupper. Flere beskriver at de har fastsatt tid til sertifisering og/eller prosedyrearbeid fra én til fire dager i året i turnus.

Utover dette er det ikke avsatt tid eller ressurser til å oppdatere seg faglig ved for eksempel å lese fag- og forskningsartikler. En fokusgruppedeltaker peker på dette: «Hvis en hadde mer personale, slik at en kunne få tid til å sitte og jobbe med faget en gang iblant, ja legge det inn i turnus, for vår hverdag er så hektisk at det er lite tid til det.»

\section{Stort tidspress}

En annen deltaker i samme gruppe tilføyer følgende: «Det er så mye skruer og skrin og alt mulig at en trenger virkelig tid for å kunne sette deg inn i det, og det har du ikke på dagen.» Mange understreket at manglende kunnskaper kunne skape utrygghet når de utøvet arbeidet. Flere deltakere pekte også på at arbeidet foregår i et svært høyt tempo. Av den grunnen fremsto mange som litt resignerte overfor det å ta ansvar for eget fag. 
En erfaren deltaker beskrev hvordan

arbeidssituasjonen setter pasientsikkerheten i fare:

«Det går så fort at fortere går det ikke an å jobbe, det

blir feil, rett og slett. Vi har jobbet oss opp til et voldsomt tempo, og jeg mener at vi blir så 'effektive' til slutt at du tenker nesten ikke, har ikke med deg hodet, du bare gjør det på impulser, og jeg tror ikke det er bra.»

Det var en tendens blant alle deltakerne til at de anså eksterne faktorer som tidspress som årsaken til at de selv ikke var godt nok oppdatert eller godt nok forberedt til et inngrep, som igjen påvirket pasientsikkerheten. Flere deltakere i flere av gruppene påpekte dog at det finnes tid mellom arbeidsoppgavene, men at denne tiden ikke brukes til å oppdatere seg faglig. En deltaker sa det slik: «Ja, det har vi jo [tid], men det er ikke alltid at du prioriterer det kvarteret der, det gjør i alle fall ikke jeg.»

\section{Må bruke fritiden til faglig oppdatering}

I diskusjonene rundt ansvaret for å heve egen kompetanse snakket de om hvorvidt de kunne tenke seg å bruke fritiden på faglig oppdatering. En grunnleggende holdning blant deltakerne var at «fritiden er hellig». Mange argumenterte med at operasjonssykepleiere har et svært krevende arbeid, og at de dermed ikke har overskudd til å søke, lese og vurdere fag- og forskningsartikler på fritiden.

En deltaker uttrykte sin mening om dette på følgende måte: «Det er ikke satt av tid til at jeg kan sette meg ned på nettet og innhente kunnskap eller å søke, da må jeg gjøre det på fritiden, og der er ikke jeg, det er jeg ikke!»

Flere av deltakerne fra fokusgruppene fortalte at deres avdeling har ett eller flere rom med pc som kan benyttes til å søke etter og lese fag- og forskningsartikler. Det fremkom at rommene først og fremst ble benyttet til samtaler og spiserom, - samt et sted der de snakket om private ting. 
En deltaker beskrev det slik i en av fokusgruppene:

«Vi har fire pc-er egentlig, vi kan sitte på pauserommet og gå inn og sjekke hvis vi ønsker noe, hvor vi spiser, og vi kan gå inn i kroken der hvor legene ofte sitter, eller vi kan gå inn på det lille rommet, eller vi kan gå inn på rommet ved siden av ...»

En annen deltaker fra en annen fokusgruppe ga en liknende kontekstbeskrivelse: «Vi har fått et fordypningsrom hvor vi skal kunne sitte på slutten av dagen og fordype oss og sånne ting, men der diskuteres det alt fra togtider til matoppskrifter, og det er vanskelig å sitte der og jobbe.»

I samtlige fokusgrupper var de enige om at muligheten til å søke fag- og forskningslitteratur reelt sett var til stede. Likevel fremgikk det av diskusjonene at denne tiden og rommene i hovedsak ble brukt til å hvile eller snakke med kollegaer.

\section{Kompetanse og kunnskap knyttet til kunnskapsbasert praksis}

Fokusgruppediskusjonene viser at det å søke etter relevant forskningslitteratur, ikke representerer en naturlig del av arbeidsdagen eller det de anser som en naturlig arbeidsoppgave. Deltakerne synes søkeprosessene er vanskelige, at de ikke har kompetanse til å utføre litteratursøk riktig eller grundig nok. Denne mangelen på kompetanse vises blant annet ved at flere av deltakerne ikke vet hvilke databaser de kan søke i.

I tillegg foretrekker mange å lese norsk litteratur. En deltaker sa det slik: «Jeg vet ikke hvor jeg kan finne artikler om operasjonssykepleie og behandling, og jeg liker best å lese på norsk. Engelsk er for vanskelig.» 
Noen deltakere peker på at de generelt er dårlige til å håndtere pc: «Du har ikke mye tid til å gå inn på dataen, jeg er for øvrig veldig dårlig på databruk.» Videre kom det frem at det er mer vanlig å surfe på nettet etter ulike sykdommer og det man har mest interesse av, enn å søke aktivt etter fagfellevurdert forskning. Enkelte fortalte at de fortrakk å benytte Google fremfor de medisinske databasene: «Hvis det er ting jeg lurer på, diagnoser for eksempel, er jeg raskt fremme med telefonen, og jeg finner masse bare ved å google det på internett.»

\section{三 «Enkelte fortalte at de fortrakk å benytte Google fremfor de medisinske databasene.»}

Flere responderte på slike innspill ved å peke på at det de finner på internett, ikke nødvendigvis har god kvalitet. Det kom også frem av diskusjonene at deltakerne syntes det var vanskelig å vurdere kvaliteten og forskjellen på fag- og forskningsartikler. De syntes dessuten det var vanskelig å vurdere hvor på nettet de finner det som er faglig forsvarlig å forholde seg til.

\section{Vanskelig å ta i bruk forskningsresultater}

Et annet moment som ble nevnt i en av fokusgruppene, var motstand fra ledelsen mot forsøk på å implementere nye tiltak basert på nyere forskning, ofte gjennom tilbakemeldinger som denne: «Sånn gjør vi det ikke her.»

I de andre fokusgruppene var det en generell tendens til at deltakerne ikke visste hvordan de kunne initiere bruk av forskningsresultater for å forbedre praksisen, samtidig som de opplevde at det finnes lite relevant sykepleieforskning.

Deltakerne hadde gjennomført sin operasjonssykepleierutdannelse i både ut- og innland, og funnene viser ingen klare tendenser til forskjeller ut fra bakgrunn eller hvor deltakerne arbeidet når det gjaldt å arbeide kunnskapsbasert. 


\section{Diskusjon}

Mange av deltakerne pekte på ulike barrierer mot å arbeide kunnskapsbasert. I studien vår innebærer slike barrierer å inkludere forskningsbasert kunnskap ved siden av erfaringsbasert og brukerbasert kunnskap. Barrierene er knyttet til knapphet på tid og ressurser samt manglende organisatorisk tilrettelegging, manglende engasjement hos ledelsen, men også noe manglende personlig engasjement.

Det er usikkert hvor mange pasienter som dør på sykehus på grunn av pasientskader, men det finnes nok kunnskap til at vi kan si at antall pasientskader er vesentlig $(6,19)$. For å kunne redusere antallet må vi øke kunnskapen om årsakene som fører til pasientskader og dødsfall (19). For å unngå at uheldige hendelser oppstår, bør man styrke helsepersonellets fagkunnskap og -kompetanse.

Den norske legeforening (19) påpeker at i tillegg til å identifisere årsaker til feil, må man kartlegge hvilke faktorer som hindrer åpenhet knyttet til disse feilene. Pasientsikkerhet skapes i virksomheten, og ved å sikre større grad av åpenhet og trygghet ved rapportering av avvik kan også oppfølging og læring skje. Pasientskader og uheldige hendelser er en samfunnsøkonomisk belastning, og styringslinjen i helseforetakene bør derfor hele tiden fokusere på kvalitet og sikre kompetanse til dem som utøver helsetjenestene $(1,6,19)$.

\section{Ikke avsatt tid til fagutvikling}

Funnene i denne studien viser at enkelte avdelinger har avsatt tid til sertifisering og prosedyrer i turnus, men utover dette er det ikke avsatt tid til egen fagutvikling. Samtidig kan helsepersonell selv aktivt benytte seg av de mulighetene som finnes for å sikre slik kompetanse, og dermed bidra til at oppdatert kunnskap implementeres i klinikken (19, 21-23). 
Det er både avdelingens ansvar og hver enkelt operasjonssykepleiers ansvar å legge forholdene til rette slik at man kan arbeide kunnskapsbasert $(5,24)$. Det kan dog tenkes at sykepleiere i større grad ville identifisert ansvaret de har for å arbeide kunnskapsbasert hvis organisatoriske tiltak som sikret tid til dette arbeidet, ble prioritert og synliggjort i turnusplanene.

\section{三 «Det er både avdelingens ansvar og hver enkelt operasjonssykepleiers ansvar å legge forholdene til rette slik at man kan arbeide kunnskapsbasert.»}

Funn fra en litteraturgjennomgang (25) påpeker dessuten betydningen av at utdanningsinstitusjoner utarbeider programplaner der læringsaktiviteter er knyttet til KBP (25). Ved å ta i bruk et systematisk opplæringsprogram i tett samarbeid med praksis vil kunnskapen om KBP øke både hos operasjonssykepleierne i praksisfeltet og hos studentene (25).

\section{KBP må inn i utdanningen}

Vi har lest gjennom programplaner ved ulike høyskoler på deres nettsider samt hatt muntlig samtale med ulike representanter fra ulike høyskoler. Det kan synes som at det fremdeles er høyskoler i landet som ikke har KBP inkludert som emne i programplanen, selv om det har eksistert et krav fra Helse- og omsorgsdepartementet om at KBP skal være implementert blant både lærere og helsearbeidere innen 2015 (26). Utdanningsinstitusjonene kan derfor ta et større ansvar for å integrere og implementere arbeid med KBP i sine programplaner. 
Ved å vektlegge konkrete læringsaktiviteter som å søke, lese, forstå og vurdere forskningsartikler og ulikt forskningsdesign kan sykepleiere og de som spesialiserer seg, lære å arbeide kunnskapsbasert i studietiden. Kontaktsykepleiere, veiledere og lærere kan sammen med studentene bidra til å utarbeide problemstillinger som er kliniske og pasientnære. Dermed vil ansatte bli involvert og kunne se nytten av forskningen i praksis.

Dette kan igjen medføre en positiv holdning til å bruke forskning til å endre praksis (10, 12, 13, 28). I tillegg kan de gjennomføre kurs og opplæringsprogrammer i KBP. Ressurspersoner på avdelingsnivå, som fagsykepleiere, kan benyttes til å lære opp andre ansatte (12, 29). Mer kunnskap vil kunne skape større trygghet, og større trygghet vil kunne gi positive holdninger til det å kontinuerlig arbeide kunnskapsbasert (12, 28).

\section{Operasjonssykepleierne må ta mer ansvar}

Det fremgår av funnene at operasjonssykepleierne arbeider i et høyt tempo, og de mener selv de står i fare for ikke å utøve sykepleieroppgavene på en trygg og forsvarlig måte. Funnene antyder likevel at operasjonssykepleiere tar lite ansvar for å jobbe kunnskapsbasert. Det vil si at de fremviser relativt lite engasjement for selv å sørge for å være oppdatert på relevant kunnskap for å kunne utøve forsvarlig sykepleie. Argumentene synes å inneholde aksept for at det å arbeide kunnskapsbasert, må vike for krav til produksjon og effektivitet.

\section{三 «Funnene antyder at operasjonssykepleiere tar lite ansvar for å jobbe kunnskapsbasert.»}


I 1990-årene ble det innført en ny «offentlig styring», New Public Management, som er uttrykt i helseforetaksreformen, samhandlingsreformen og fusjoneringen av sykehusene (15). Ifølge Wyller og medarbeidere (15) er et av kjennetegnene i styringsstrategien at det er et krav om lojalitet til ledelsen. Dette kravet medfører at det personlige ansvaret profesjonsutøveren har for å ivareta pasienten, blir erstattet med krav om lojalitet til lederne, som videre må være lojale overfor sine ledere.

Profesjonsutøvere omdannes til disiplinerte funksjonærer, der blant annet hver enkelt vurdering og derav forsvarlighet blir fortrengt av det som blir bestemt på et høyere nivå (15). Man kan derfor stille spørsmål ved hvorvidt ansvarsfraskrivelsen og krav om forsvarlighet ligger hos den enkelte, eller hvorvidt det er et resultat av organisasjonenes ledelsesstruktur $(4,10,19,30)$. Funnene i studien antyder en ansvarsfraskrivelse fra flere ledd i praksisfeltet.

\section{Konklusjon}

Studien viser manglende kompetanse samt en manglende organisatorisk struktur og kultur som underbygger og støtter opp om KBP både i operasjonsavdelingene og i utdanningsinstitusjonene. Funnene antyder at dette kan ses i sammenheng med manglende tilrettelegging, men også manglende engasjement, både på individuelt og organisatorisk plan.

Det er behov for systematisk opplæring og oppfølging for å øke kunnskapen om KBP, både i operasjonsavdelingene og i utdanningsinstitusjonene. Ved å fokusere både på avdelingsnivå og på relevante utdanningsinstitusjoner kan vi oppnå en synergieffekt som kan medføre en holdningsendring som bedre ivaretar alle elementene som kunnskapsbasert praksis består av.

\section{Referanser}


1. Helsetilsynet. Alvorlige hendelser i kirurgiske fag. Rapport 5/2015.

2. Lov 2. juli 1999 nr. 64 om helsepersonell m.v. (helsepersonelloven). Tilgjengelig fra:

https://lovdata.no/lov/1999-07-02-64 (nedlastet 12.01.2013).

3. Markussen K. Barriers to research utilization in clinical practice (review). Vård i Norden. 2007;3:47-9.

4. Helsedirektoratet. I trygge hender 24-7:

pasietsikkerhetsprogrammet.no [internett]. Oslo:

Helsedirektoratet [sitert 12.10.2016]. Tilgjengelig fra: http://www.pasientsikkerhetsprogrammet.no/.

5. Meld. St. nr. 11 (2015-2016). Nasjonal helseog sykehusplan. Oslo: Helse- og omsorgsdepartementet; 2015. Tilgjengelig fra: https://www.regjeringen.no/no/dokumenter/meld.st.-11-20152016/id2462047/ (nedlastet 13.03.2018).

6. Norsk pasientskadeerstatning (NPE). Statistikk for regionale helseforetak 2015. Tilgjengelig fra: https://www.npe.no/globalassets/dokumenter-pdf-ogpresentasjoner/rapporter/rhf_rapport_2015.pdf (nedlastet 20.10.2016).

7. Nortvedt MW, Jamtvedt G. Kunnskapsbasert praksis: Engasjerer og provoserer. Sykepleien.2009;97(7):64-9. Tilgjengelig fra: https://sykepleien.no/forskning/2009/04/engasjerer-ogprovoserer (nedlastet 27.02.2018).

8. Hommelstad J, Ruland CM. Norwegian nurses perceived barriers and facilitators to research use. AORN Journal. 2004;79(3):621-34.

9. Rasmussen RS. Anestesisykepleiers holdning til fagutvikling. (Masteroppgave.) Oslo: Høgskolen i Oslo, Avdeling for sykepleieutdanning; 2011. 
10. Sandvik GK, Stokke K, Nortvedt MW. Hvilke strategier er effektive ved implementering av kunnskapsbasert praksis i sykehus? Sykepleien Forskning 2011;6(2):158-65. Tilgjengelig fra: https://sykepleien.no/forskning/2011/05/hvilkestrategier-er-effektive-ved-implementering-avkunnskapsbaser-praksis-i (nedlastet 27.02.2018).

11. Snibsøer AK, Olsen NR, Espehaug B, Nortvedt M. Holdning og atferd knyttet til kunnskapsbasert praksis. Sykepleien Forskning 2012;7(3):232-41. Tilgjengelig fra: https://sykepleien.no/forskning/2012/10/holdningog-atferd-knyttet-til-kunnskapsbasert-praksis (nedlastet 13.03.2018).

12. Thidemann I-J. Den sårbare læringsarenaen om praksisfellesskapets implikasjoner for sykepleieres læring og kompetanseutvikling. Vård i Norden. 2005;75(25):10-5.

13. Bratberg G, Haugdahl Hege S. Opplæring i kunnskapshåndtering - nytter det? Sykepleien Forskning. 2010;5:192-9. Tilgjengelig fra: https://sykepleien.no/forskning/2010/10/opplaering-ikunnskapshandtering-nytter-det (nedlastet 27.02.2018).

14. Flodgren G, Rojas-Reyes MX, Cole N, Foxcroft DR. Effectiveness of organisational infrastructures to promote evidence-based nursing practice. Cochrane Database of Systematic Reviews. 2012;2:1-21.

15. Wyller VB, Gisvold SE, Hagen E, Heggedal R, Heimdal A, Karlsen K, et al. Ta faget tilbake.

Tidsskrift for Den norske legeforening. 2013;133(6):655-9.

16. Halkier B. Fokusgrupper. Oslo: Gyldendal Norsk Forlag; 2010. 
17. De nasjonale forskningsetiske komiteene.

Generelle forskningsetiske retningslinjer. Oslo: De nasjonale forskningsetiske komiteene;

2014. Tilgjengelig fra:

https://www.etikkom.no/forskningsetiske-

retningslinjer/Generelle-forskningsetiske-

retningslinjer/ (nedlastet 13.03.2018).

18. Malterud K. Kvalitative metoder i medisinsk forskning: En innføring. 3. utg. Oslo:

Universitetsforlaget; 2011.

19. Den norske legeforening. Oppfølging av uheldige hendelser og feil i helsetjenesten. Innspill til utvalg. Oslo: Den norske legeforening; 2014.

Tilgjengelig fra: http://docplayer.me/5422997Oppfolgning-av-uheldige-hendelser-og-feil-ihelsetjenesten.html (nedlastet 05.03.2018).

20. Lov 2. juli 1999 nr. 61 om spesialisthelsetjenesten m.m.

(spesialisthelsetjenesteloven). Tilgjengelig fra: https://lovdata.no/dokument/NL/lov/1999-07-02-61 (nedlastet 12.01.2013).

21. Hogan H, Healy F, Graham N, Thomson R, Vincent C, Black I. Preventable deaths due to problems in care in English acute hospitals: a retrospective case record review study. BMJ Quality \& Safety. 2012;21(9):737-45.

22. Naustdal AG. Kompetanseutvikling under press - erfaringer til sjukepleieleiarar etter omorganisering av sjukehusa. Sykepleien Forskning 2010;5(4): 286-92. Tilgjengelig fra: https://sykepleien.no/forskning/2011/01/kompetanseutviklingunder-press-erfaringer-til-sjukepleieleiarar-etter (nedlastet 27.02.2018).

23. Odland LH. Evidens - et sentralt begrep i profesjonell sykepleie? Nordisk tidsskrift for helseforskning. 2010;6(1):101-4. 
24. Spruce L. Back to basics: implementing evidence-based practice. AORN Journal.

2015;101(1):106-14.

25. Erichsen T, Røkholt G, Utne I.

Kunnskapsbasert praksis i sykepleieutdanningen.

Sykepleien Forskning. 2016;1(11):66-76. Tilgjengelig

fra:

https://sykepleien.no/forskning/2016/02/kunnskapsbasert-

praksis-i-sykepleierutdanningen (nedlastet

27.02.2018).

26. Sosial- og helsedirektoratet. Hvordan kommer vi fra visjoner til handling? ... og bedre skal det bli!

Praksisfeltets anbefalilnger for å oppnå god kvalitet på tjenestene i sosial- og helsetjenesten. Oslo: Sosial- og helsedirektoratet; 2007. Tilgjengelig fra: https://helsedirektoratet.no/Lists/Publikasjoner/Attachments/645/Hvordankommer-vi-fra-visjoner-til-handling-og-bedre-skal-detbli-IS-1502.pdf (nedlastet 13.03.2018).

27. Ulvund I, Grønvik CKU. Lærer å jobbe kunnskapsbasert. Sykepleien. 2016;104(5):44-7.

Tilgjengelig fra:

https://sykepleien.no/forskning/2016/04/laerer-jobbekunnskapsbasert (nedlastet 27.02.2018).

28. Grønvik CKU, Julnes SEG, Ødegård A. En kvalitativ studie av sykepleiestudenters opplevelser av nye læringsaktiviteter i kritisk vurdering av kvantitative forskningsartikler. Nordisk tidsskrift for helseforskning. 2014;2:91-105.

29. Christiansen B, Carlsten TC, Jensen K.

Fagutviklingssykepleier som brobygger mellom forskning og klinisk praksis. Sykepleien Forskning. 2009;4(2):100-6. Tilgjengelig fra:

https://sykepleien.no/forskning/2009/06/fagutviklingssykepleierensom-brobygger-mellom-forskning-og-klinisk-praksis (nedlastet 27.02.2018). 
30. Opheim AE. Fagutvikling må prioriteres.

Sykepleien Forskning. 2010;5(4): 293. Tilgjengelig

fra: https://sykepleien.no/2011/01/fagutvikling-ma-

prioriteres (nedlastet 27.02.2018). 